\title{
УДК 159.942.5:17.022.1
}

ГАВРИЩАК Любов - кандидат психологічних наук, доцент кафедри практичної психології, Дрогобицький державний педагогічний університет імені Івана Франка, 24, вул. Івана Франка, м. Дрогобич, Україна, індекс 82100 (ljubadrogobych@gmail.com)

БОРИСЕНКО Зоряна - кандидат психологічних наук, доцент кафедри практичної психології, Дрогобиџький державний педагогічний університет імені Івана Франка, 24, вул. Івана Франка, м. Дрогобич, Україна, індекс 82100 (adurkalets@ukr.net)

ORCID: https://orcid.org/0000-0002-5084-0361

DOI: https://doi.org/10.24919/2312-8437.45.196994

Бібліографічний опис статті: Гаврищак, Л., \& Борисенко, 3. (2019). Щастя як психологічна категорія. Проблеми гуманітарних наук: збірник наукових пращь Дрогобищького державного педагогічного університету імені Івана Франка. Серія «Психологія», 45, 39-51. doi: 10.24919/2312-8437.45.196994.

\section{ЩАСТЯ ЯК ПСИХОЛОГІЧНА КАТЕГОРІЯ}

Анотація. У статті аналізуються дослідження психологів стосовно категорії «щастя». Зокрема обсервуються психологічні особливості та показники щзасливого життя, визначається спільне й відмінне між такими поняттями, як «щастя», "суб'єктивне благополуччя» $i$ «життерадісність».

Ученими запропоновано модель суб 'єктивного благополуччя, яка складається з таких основних взаємозалежних компонентів: позитивні емоції, які переживаються часто; негативні емочії як афективний компонент благополуччя, які трапляються рідко; когнітивна очінка або «глобальні судження» задоволеності життям.

Радість - ие емоційний бік щуастя, а задоволення - когнітивний.

Чинники щуастя с одночасно і джерелами, умовами та сферами задоволення життям, а деколи й особистісними характеристиками людини.

(C) Гаврищак Любов, Борисенко Зоряна, 2019 
Для відчуття щастя необхідно дотримуватися двох способів саморегуляиії ї̈ мотивації до світу: особистісне підвищення значущості людей та збільшення власних можливостей.

Поряд з терміном «щастя» вжсиваються й інші, такі як «суб'єктивне благополуччя» та «життєрадісність». "Суб'єктивне благополуччя» складається з психологічного, фізичного та сочіального добробуту. Такі терміни не тотожні. Вони досить незалежні, хоча й подібні. Щастя - ие гостре та інтенсивне відчуття, інші терміни за силою вираження є слабшими. Найбільш скороминуще - це почуття щастя. Більш тривалим є психологічний добробут. Найдовше - це задоволення від життя.

Авторами проаналізовані психологічний, фізичний та сочіальний компоненти суб 'єктивного благополуччя, а також у статті визначені зовнішні (об'єктивні) та внутрішні (суб'єктивні) чинники щастя. Учені розрізняють зовнішні (здоров'я, доходи, робота, соціальний статус, освіта, вік, стать, релігія, дозвілля), внутрішні (невротизм, екстраверсія, радість, любов) та суб'єктивні (оцінка суб'єкта відповідно до його життєвих установок) детермінантами щастя. Людське щастя полягає саме у своєрідному поєднанні циих факторів.

Ключові слова: щастя; психологічні аспекти щзастя; суб'єктивне благополуччя; задоволеність життям.

HAVRYSHCHAK Lyubov - Candidate of Psychological Sciences, Associate Professor, Department of Practical Psychology, Drohobych Ivan Franko State Pedagogical University, 24 Ivan Franko Str., Drohobych, Ukraine, postal code 82100 (ljubadrogobych@gmail.com)

BORYSENKO Zoryana - Candidate of Psychological Sciences, Associate Professor, Department of Practical Psychology, Drohobych Ivan Franko State Pedagogical University, 24 Ivan Franko Str., Drohobych, Ukraine, postal code 82100 (adurkalets@ukr.net)

ORCID: https://orcid.org/0000-0002-5084-0361

DOI: https://doi.org/10.24919/2312-8437.45.196994

To cite this article: Havryshchak, L., \& Borysenko, Z. (2019). Shchastia yak psykholohichna katehoriia [Happiness as a psychological category]. Problemy humanitarnych nauk: zbirnyk naukovych prats Drohobytskoho derzhavnoho pedahohichnoho universytetu imeni Ivana Franka. Seriia «Psykholohiia» - Problems of Humanities. «Psychology» Series: a collection of scientific articles of the Drohobych Ivan Franko State Pedagogical University, 45, 39-51. doi: 10.24919/2312-8437.45.196994 [in Ukrainian]. 


\section{HAPPINESS AS A PSYCHOLOGICAL CATEGORY}

Abstract. The article analyzes the research of the category of «happiness»; in particular, psychological characteristics and indicators of a happy life, determines common and different features between such concepts as «happiness», "subjective well-being》 and "cheerfulness».

The psychologists propose a model of subjective well-being, which consists of the following main interconnected components: recurrent positive emotions; negative emotions as an affective component of well-being that are rare; cognitive assessment or "global judgment» of life satisfaction.

Joy is the emotional side of happiness, and pleasure is the cognitive side of happiness.

The happiness factors are simultaneously sources, conditions and areas of satisfaction with life, and at times personal characteristics of a person.

In order to feel happiness, it is necessary to observe two ways of self-regulation of its motivation for the world: a personal increase in the significance of people and an increase in their own capabilities.

Along with the term "happiness» other terms are used as well, such as "subjective well-being》 and "cheerfulness》. "Subjective wellbeing» consists of psychological, physical and social well-being. Although they have similarities, such terms are not identical and quite independent. Happiness is a sharp and intense sensation; from the point of view of expression other terms are weaker. The most transitory is a feeling of happiness. The longer is the psychological well-being, the longer is the pleasure of life.

The authors analyze the psychological, physical and social components of subjective well-being, and the article also defines the external (objective) and internal (subjective) factors of happiness. They distinguish between external (health, income, work, social status, education, age, gender, religion, leisure), internal (neuroticism, extraversion, joy, love) and subjective (assessment of the subject in accordance with his life settings) determinants of happiness. Human happiness lies precisely in a peculiar combination of these factors.

Keywords: happiness; psychological aspects of happiness; subjective well-being; life satisfaction.

Постановка проблеми. Сучасна культура демонструє найактивніший інтерес до проблеми щастя, дефіцит якого відчува- 
ється у сучасному суспільстві. Причини ментального нездоров'я i депресії багато хто вбачає у ринкових соціальних інститутах. Різноманітні дослідження феномену щастя, зроблені останнім часом філософами, соціологами, психологами, свідчать про актуальність теми і про наявність у ній нерозв'язаних теоретичних проблем.

Аналіз останніх публікацій. Представники різних теоретичних течій у наукових студіях зверталися до проблематики щастя, а основним напрямом стала гуманістична психологія. Ученими розглядаються різні аспекти аналізу щастя, робиться акцент на його поясненні як особистого та суспільного феномену. Дослідженням чинників щастя займалися М. Аргайл; С. Жубаркін аналізував уявлення провінційної молоді про щастя у контексті емоційно-мотиваційної спрямованості; психосемантичний аналіз уявлень про щастя китайських і російських студентів здійснено Н. Виничуком; уявлення про щастя у жінок вивчав С. Маслаков; людське щастя як соціокультурний феномен досліджувався А. Шамсетдіновою; соціально-філософський аналіз феномену щастя зроблено Є. Мішутіною; І. Джідарьян розроблено основи психології щастя і оптимізму тощо.

Мета статті - здійснити аналіз теоретичних підходів до визначення категорії щастя у вітчизняній і зарубіжній психології.

Виклад основного матеріалу дослідження. У процесі пошуку визначень та змісту феномену «щастя» вчені пропонували різноманітні його визначення, апробували різні теоретичні підходи і концепції. Поняття «щастя» сьогодні не має чіткого визначення, і як відзначає В. Татаркевич: «Різні поняття щастя мають тільки те спільне, що позначають щось позитивне, цінне, в іншому ж розумінні вони різняться між собою» (Титаренко, 2017). Незважаючи на те, що при визначенні цього феномену вчені стикаються 3 великими труднощами, спроби зрозуміти його зміст і виміряти його робилися з середини минулого століття і робляться сьогодні філософами, соціологами, психологами. У зв’язку з цим щастя як дослідницька категорія вважається міждисциплінарним феноменом.

Проблема щастя і його компонентів привертала увагу багатьох психологів-дослідників. Перші емпіричні дослідження щастя припадають на 30-ті pp. XX ст. Найбільш раннє анкетне опи- 
тування, присвячене з'ясуванню джерел щастя, було проведено на початку XX ст. американським психологом Дж.Б. Уотсоном.

У другій третині XX ст. під впливом робіт А. Маслоу, Р. Мея, Р. Олпорта, К. Роджерса, В. Франкла, Е. Еріксона та інших, категорія щастя активно досліджується представниками позитивної психології М. Селігманом, Дж. Вейланатом, Д. Майєрсом, Е. Дінером, К. Ріффом та ін.

Англійський дослідник М. Аргайл, здійснивши аналіз західноєвропейських та американських досліджень щастя, узагальнивши їх, відзначає: «щастя, яке найчастіше визначається як переживання радості, - це єдиний фактор людського досвіду, однак воно складається меншою мірою з трьох, частково незалежних факторів: задоволеності життям, позитивних емоцій і відсутності негативних емоцій, до того ж радість - це емоційна сторона щастя, а задоволеність - когнітивна, це рефлексивна оцінка, судження про те, наскільки все було і залишається благополучним» (Аргайл, 2003).

Ученим укладено перелік чинників щастя, які одночасно виступають і як джерела, і як умови, і як сфери задоволеності життям, а іноді і як характеристики самого суб'єкта - сукупність особистісних рис життя індивіда, що піддаються визначенню, вимірам і виявляють статистично значущий зв'язок із задоволеністю життям (Аргайл, 2003). В основі щастя, на думку М. Аргайла, лежить радість від спілкування з близькими людьми, коханими та психологічної підтримки, яку вони надають індивіду.

Як форму переживання повноти буття, пов'язаного з самосправдженням, визначає щастя О. Кронік. Ядром його теорії $\epsilon$ пошук психологічних засобів набуття щастя, які вчений розуміє як способи саморегуляції людиною своєї мотивації до світу. Ним виділено дві форми такої саморегуляції: посилення людиною значущості світу і посилення своїх можливостей, в основі яких лежать принципи максимізації користі та здібностей, мінімізації потреб і складнощів. Залежно від індивідуальних та соціальних умов, уявлень людини про шляхи здобуття щастя реалізуються ці принципи (Кроник \& Ахмеров, 2003).

І. Джідарьян, О. Леонтьєв, Д. Леонтьєв, Б. Додонов, О. Ільїн і інші розглядають щастя як цінність і як афективний стан, а дже- 
релом щасливого буття вважалося досягнення певної мети, досягаючи якої людина може відчути щастя (Леонтьев, 1975).

Як стверджував Ф. Хоппе, щастя, радість приносить досягнення людиною не будь-якої мети, а лише досить важкої і водночас посильної.

На думку М. Шеколи, щастя - це колекція щасливих моментів. При цьому суб'єктивне відчуття щастя може бути як особистісною характеристикою, так і просто станом.

Американський психолог М. Абрахам убачав щастя людини в іiі самоактуалізації, шлях до якої лежить через задоволення найпростіших потреб у їжі, воді й безпеці та потреби у визнанні. Людина, що самоактуалізується, спокійна, впевнена в собі, талановита, поблажлива, не схильна до депресій та істерик, при цьому має здорову самооцінку і гармонійний зовнішній вигляд.

Ключовою ідеєю психологічних мотиваційних теорій $є$ твердження, що щастя і задоволення від життя пов'язані з внутрішньою мотивацією, тобто з почуттям самореалізації - участь у діяльності, яка подобається і $є$ необхідною. Прибічники цієї теорії пояснюють, що зовнішня мотивація, наприклад, як влада або гроші, сприяють зростанню почуття контролю, але не дають можливості відчувати почуття щастя, оскільки людина бере участь у діяльності тому, що повинна.

Представником теорії щастя як людської діяльності є Б. Фредкінсон, яка вказує на важливу роль внутрішніх факторів у переживанні почуття щастя. На іï думку, позитивні емоції сприяють творчості та продуктивності, а це, зі свого боку зумовлює їх збільшення, створюючи цикл щастя.

Через неоднозначність і спірність у деяких психологічних дослідженнях поряд із терміном «щастя» використовуються й інші як взаємозамінні.

Як науковий синонім до категорії «щастя», М. Селігманом було введено поняття «суб'єктивне благополуччя» (Subjective well-being) (Селигман, 2006). Науковець пояснював цю взаємозамінність тим, що обидва поняття не мають чуттєвого компонента, а включають як позитивні почуття і відчуття, наприклад, захоплення, так і позитивні види діяльності, що пов'язані із захопленнями. Однак «щастя» $\mathrm{i}$ «благополуччя» іноді пов'язані 3 
емоціями, а іноді - 3 діяльністю, яка змушує людину відмежуватися від емоцій (Селигман, 2006).

Як рівнозначне до цих понять, М. Селігман використовує також поняття «життєрадісність», відчуття якого залежить від задоволення чи незадоволення життям. Ученим було запропоновано формулу щастя: стійкість переживання щастя $є$ генетично обумовленою, тобто залежить від рівня «щасливості», який вона успадкувала від своїх рідних, а також залежить від самої людини факторів та обставин їі життя.

Щастя, на думку М. Селігмана, полягає не тільки в тому, щоб примножити приємні одномоментні суб'єктивні відчуття (Селигман, 2006). Для справжнього щастя необхідне справжнє життя, а саме позитивні якості і духовне задоволення, тобто життя, насичене позитивними емоціями.

На відміну від М. Селігмана, М. Соколової, Р. Шаміонова та інших, які в поняття «суб'єктивне благополуччя» включали психологічне, фізичне та соціальне благополуччя, Е. Дінер, К. Ріфф, А. Созонтов та інші, це поняття розглядали як складник психологічного благополуччя, уважаючи, що основою щастя $\epsilon$ процеси, незалежні від економічного процвітання. Ученим було запропоновано модель суб'єктивного благополуччя, яка складається 3 трьох взаємозалежних компонентів:

1) позитивні емоції, які переживаються часто;

2) негативні емоції як афективний компонент благополуччя, які рідко трапляються;

3) когнітивна оцінка або «глобальні судження» задоволеності життям.

На противагу Е. Дінеру, який поняття «суб'єктивне благополуччя» уважає синонімом до поняття «щастя», Ш. Стайл не ототожнює їх. Ми погоджуємося з думкою ученої, яка стверджує: «психологічне благополуччя свідчить, що людина повноцінно функціонує психологічно, навіть якщо у цей момент вона не почувається щасливою» (Стайл, 2013).

Щастя і задоволеність життям, на думку Ш. Стайл, є показниками самореалізації та загального благополуччя. Однак лише коли будуть задоволені всі основні психологічні потреби людини, вона зможе досягти справжнього процвітання. А суб'єктивне благополуччя, стверджує вона, полягає у тому, як з суб'єк- 
тивного погляду людина оцінює своє життя і те, наскільки вона щаслива. Воно поєднує у собі задоволеність життям, коли людині подобається іiі життя і вона вважає, що живе добре, та позитивні емоції, які залежать від того, як людина будує своє життя (Стайл, 2013).

Ш. Стайл виокремлює два стани/типи щастя:

1) хвилинне, проявами якого є радість, задоволення і насолода;

2) відчуття задоволеності, яке триває довше і приносить глибоке почуття благоденства, передбачає розкриття справжнього потенціалу та самореалізацію особистості.

Проте вчена не рекомендує надавати перевагу одному 3 них, аргументуючи, що коли люди почнуть порівнювати обидва стани, то можуть упустити і миттєве, і тривале щастя, які є важливими у житті людини. «Часто те, що дає насолоду в наших діях, стає ключем до розкриття нашої здатності ставити та досягати більш цікавих і значимих цілей, реалізовувати свій потенціал» (Стайл, 2013).

Аналізуючи поняття щастя, задоволення життям і благополуччя, Т. Титаренко відзначає, що вони не $є$ тотожними, а достатньо самостійними, хоча вони подібні у тому, що позначають переживання. Щастя, навіть у словосполученні «тихе щастя», відображає гостроту й інтенсивність переживання.

Задоволення життям і благополуччя за силою прояву $є$ слабшими від попереднього - супроводжуються м'якими, «Тихими» переживаннями. Різниця між цими двома поняттями полягає у тому, що людина розуміє і переживає задоволеність життям, а психологічне благополуччя за силою переживання відчувається найслабше: доки воно $є$, людина може не помічати. Коли людина переживає щастя, їй здається, що вона задоволена життям і благополучна, проте, як відзначає Т. Титаренко (2017), можна жити благополучно, переживати задоволення життям і багато позитивних емоцій, але не відчувати себе щасливим.

На суб'єктивність цих понять вказує і той факт, що людина, яку інші вважають щасливою, благополучною, задоволеною життям, насправді такою себе не вважає, і навпаки людина, яку вважають неблагополучною, незадоволеною життям, може вважати себе найщасливішою у світі. У зв'язку з цим Т. Титаренко відзначає, що щастя не виставляють на показ, його плекають, обері- 
гають, тому про його переживання інші можуть не здогадуватися, а усвідомлення того, що щастя минуло, приходить, коли з певних причин його вже нема (Титаренко, 2017).

Особливою рисою названих понять, що аналізується у науковій літературі, є їхній часовий вимір (час існування). Е. Дінер уважає, що, незважаючи на вплив на задоволеність життям у поточний момент настрою, і конкретних життєвих подій, і фізичного стану, і навіть погодних умов, рівень суб'єктивного відчуття щастя $є$ досить стабільним у часі показником для кожної людини. Ця стійкість значною мірою зумовлена особистісними характеристиками, саме особистість є одним із найсильніших предикторів суб'єктивного.

Роздумуючи над силою тривалості відчуття щастя, задоволеності життям і благополуччя, Т. Титаренко зазначає, що найбільш скороминучим є відчуття щастя, яке може тривати лише одну мить. Більш тривале психологічне благополуччя, констатація якого є результатом когнітивної й емоційної оцінки актуального стану речей та відповідних до них переживань. Оскільки задоволеність життям включає увесь попередній життєвий шлях людини, то воно $є$ найтривалішим.

Якщо аналізувати ці поняття за смисловим наповнення, то найвагомішим $є$ «благополуччя», бо якщо людина відчуває, що отримала «благо», то іншого вона не може бажати - вона і щаслива, і по-справжньому задоволена життям (Титаренко, 2017).

Залежність рейтингу щастя і задоволення життям від змін настрою вивчали Н. Шварц і Г. Клор, які стверджували, що люди, визначаючи чи щасливі і задоволені вони своїм життям, використовують поточний емоційний стан.

Дослідження щастя Д. Канемана, засновника гедоністичної психології, що грунтуються на вивченні швидкого і повільного мислення, тобто емоційної, інтуїтивної, усвідомленої і раціональної сторін особистості, експериментально доводять, що швидке мислення таємно впливає на величезну кількість наших життєвих виборів, і не тільки (Канеман, 2017).

Він вказував на відмінності між «Я свідомим», яке пам'ятає, згадує і «Я, яке відчуває». Перше перебуває у теперішньому, друге - у минулому, тому і продукують різні концепції щастя: 
щастя, яке відчувається у житті, і задоволення життям. На думку вченого, щастя не є синонімом благополуччя.

3 усього вищесказаного можна зробити висновок, що особистість - це насамперед рефлексивне Я особистості, а не Я чуттєве, хоча саме Я чуттєве і проживає щоденно життя певної особистості. Особистість живе у полоні пам'яті рефлексивного Я і часто робить певні дії чи вчинки саме заради нього. Це рефлексивне Я щастям вважає не реальні переживання, а задоволення людини, яке вона отримує, роздумуючи про власне життя (Канеман, 2017).

Н. Виничук (2012) виокремлює такі детермінанти щастя, як:

1) об'єктивні - зовнішні життєві обставини (здоров'я, дохід, робота, соціальний статус, дозвілля, освіта, вік, стать, релігія тощо);

2) суб'єктивні (нейротизм, екстраверсія, гумор, радість, любов тощо) - оцінка суб'єктом, відповідно до його магістральних життєвих установок, факторів, які різною мірою впливають на загальний рівень щастя.

Універсального рецепту щастя для всіх людей не існує, воно складається зі своєрідного для кожного індивіда поєднання цих факторів. При цьому, як стверджує I. Джидар'ян, людина відчуває, усвідомлює і оцінює рівень свого щастя - нещастя, благополуччя - неблагополуччя як цілісного переживання, керуючись своїми власними критеріями (Джидарьян, 2013).

Аналіз підходів до розуміння щастя і його детермінант дав підставу Н. Виничуку сформулювати визначення щастя як психологічного феномену, що характеризується «задоволеністю i свідомістю життєдіяльності людини, домінуванням позитивного емоційного стану, цілісним сприйняттям часу, позитивним ставленням до себе і навколишнього світу» (Виничук, 2012).

Значну кількість багатозначних поглядів на феномен щастя та його складові можна пояснити тим, що вони відображають етнокультурні особливості того чи того народу. Щастя, будучи ідеалом буття, має відмінності як на індивідуальному рівні, так і відповідно до етнічних та епохальних рис. Думку про те, що поняття щастя $\epsilon$ і залишається багатогранним, сповненим безліччю смислів, і відображає культурні, психологічні, економічні та соціальні домінанти, наявні у тому чи тому соціумі, - висловлює також Т. Титаренко (2017). 
Із викладеного можна виокремити філософський та психологічний аспекти проблеми щастя. Філософський аспект, аналізуючи цю категорію і шляхи іiі досягнення, акцентує увагу на категоріях «бути» і «здаватися»: більшість людей можуть здаватися щасливими i благополучними, не будучи насправді такими, що може пов'язуватися з вихованістю людини, яка вважає неприйнятним демонструвати власне благополуччя, так і з нещодавнім статусом щасливих (благополучних), який на цей момент не $є$ актуальним станом (Титаренко, 2017).

Психологічний аспект доводить суб'єктивність названих понять, відзначаючи при цьому, що єдиного для всіх розуміння чи рецепту щастя не може існувати. Якщо інші люди, оцінюючи людину, вважають іï щасливою, то вони приходять до такого висновку лише на основі власних суб'єктивних критеріїв щастя, які $\epsilon$ іншими у тієї людини, яку вони вважають щасливою. У цьому розумінні їхнє сприйняття щастя $є$ суб'єктивно-об'єктивним. Однак все ж існують окремі спільні ознаки переживання відчуття щастя, що дає змогу оцінити рівень щастя чи задоволеності життям інших людей.

Висновки. Проведений аналіз визначень та смислових значень категорії «щастя» засвідчив, що через його багатогранність у наукових колах не існує єдиного загальноприйнятого визначення. Комплексний, системний аналіз категорії «щастя» передбачає врахування філософських, релігійних, морально-етичних, психологічних, соціально-економічних та інших аспектів. Слід відзначити, що смислове наповнення цього поняття може істотно змінюватися залежно від обраного ракурсу розгляду та теоретичної позиції дослідника.

Наша позиція наближається до думки дослідників, які визначають щастя як багаторівневе комплексне психічне утворення, яке, з одного боку, опосередковане і взаємозумовлене внутрішніми фізіологічними (нейрофізіологічними) процесами, 3 іншого - зовнішніми соціально-економічними, культурними, історичними та іншими умовами, а $з$ третього, визначається особистісним змістом.

Перспективи подальшого дослідження ми вбачаємо у вивченні впливу вікових особливостей людини на їі розуміння $\mathrm{i}$ трактування власного життя як щасливого або нещасливого. 


\section{Література}

Аргайл, М. (2003). Психология счастья. Санкт-Петербург: Питер.

Виничук, Н.В. (2012). Особенности представлений психосоматических больных о счастье. Психологические исследования, 2 (22). Взято c http://psystudy.ru/index.php/num/2012n2-22/653-vinichuk22.html.

Джидарьян, И.А. (2013). Психология счастья и оптимизма. Москва: Изд-во «Институт психологии РАН».

Канеман, Д. (2017). Думай медленно ... Решай быстро. Москва: Изд. АСТ.

Кроник, А.А., \& Ахмеров, Р.А. (2003). Каузометрия. Методы самопознания, психодиагностики и психотерапии в психологии жизненного пути. Москва: Смысл.

Леонтьев, А.Н. (1975). Деятельность. Сознание. Личность. Москва: Политиздат.

Селигман, М. (2006). Новая позитивная психология: научный взгляд на счастье и смысл жизни. Москва: София.

Стайл, Ш. (2013). Позитивная психология. Что делает нас счастливыми, оптимистичнылми и мотивированными. Москва: Претекст.

Титаренко, Т.М. (2017). Щастя, здоров'я, благополуччя: досягнення недосяжного. В Т.М. Титаренко та ін. (Ред.), Ракурси психологічного благополуччя особистості: збірник тез доповідей 19 всеукраїнського науково-практичного семінару, 9 червня 2017 р., Ніжин. Ніжин: НДУ ім. М. Гоголя.

\section{References}

Argail, M. (2003). Psikhologiia schastia [Psychology of happiness]. Saint Petersburg: Piter [in Russian].

Vinichuk, N.V. (2012). Osobennosti predstavlenii psikhosomaticheskikh bolnykh o schaste [Features of representations of psychosomatic patients about happiness]. Psikhologicheskie issledovaniia - Psychological research, 2 (22). Retrieved from http://psystudy.ru/index.php/num/ 2012n2-22/653-vinichuk22.html [in Russian].

Dzhidarian, I.A. (2013). Psikhologiia schastia i optimizma [Psychology of happiness and optimism]. Moscow: Izd-vo «Institut psikhologii RAN» [in Russian].

Kaneman, D. (2017). Dumai medlenno... Reshai bystro [Think slowly... Decide fast]. Moscow: Izd. AST [in Russian].

Kronik, A.A., \& Akhmerov, R.A. (2003). Kauzometriia. Metody samopoznaniia, psikhodiagnostiki i psikhoterapii v psikhologii zhiznennogo puti [Causometry. Methods of self-knowledge, psychodiagnostics and psychotherapy in the psychology of life's journey]. Moscow: Smysl [in Russian]. 
Leontev, A.N. (1975). Deiatelnost. Soznanie. Lichnost [Activity. Consciousness. Personality]. Moscow: Politizdat [in Russian].

Seligman, M. (2006). Novaia pozitivnaia psikhologiia: nauchnyi vzgliad na schaste $i$ smysl zhizni [A new positive psychology: a scientific view of happiness and the meaning of life]. Moscow: Sofiia [in Russian].

Stail, Sh. (2013). Pozitivnaia psikhologiia. Chto delaet nas schastlivymi, optimistichnymi i motivirovannymi [Positive psychology. What makes us happy, optimistic and motivated]. Moscow: Pretekst [in Russian].

Tytarenko, T.M. (2017). Shchastia, zdorovia, blahopoluchchia: dosiahnennia nedosiazhnoho [Happiness, health's, prosperity: attainment of the unapproachable]. In T.M. Tytarenko et al. (Eds.), Rakursy psykholohichnoho blahopoluchchia osobystosti: zbirnyk tez dopovidei 19 vseukrainskoho naukovo-praktychnoho seminaru, 9 chervnia 2017 r., Nizhyn Aspects of psychological well-being of the person: Collection of Abstracts of Papers of the 19th All-Ukrainian Science and Practical Seminar, June 9, 2017, Nizhyn. Nizhyn: NDU im. M. Hoholia [in Ukrainian].

Стаття надійшла 12 лютого 2019 р. 